\title{
A Pannonhalmi Főapátsági Könyvtár kora újkori zoológia könyveinek vizsgálata*
}

\author{
BAKONYI GÁBOR ${ }^{1 *}$ és BAKONYI ZSUZSANNA ${ }^{2}$ \\ ${ }^{1}$ Szent István Egyetem, Állattani és Állatökológiai Tanszék, 2100 Gödöllő, \\ Páter K. u. 1.*E-mail: bakonyi.gabor@mkk.szie.hu \\ ${ }^{2}$ Országos Széchényi Könyvtár, Régi Nyomtatványok Tára, 1014 Budapest, \\ Szent György tér 4-6. E-mail: bakonyi.zsuzsanna@oszk.hu
}

\begin{abstract}
Összefoglalás. A Pannonhalmi Főapátsági Könyvtár hazánk legrégebbi könyvtára. Már a 11. században mintegy 200 könyvet öriztek itt. Története fordulatos, állománya többé-kevésbé folyamatosan növekedett és jelenleg több mint 400000 kötetre tehető. A magyar bencés szerzetesek között sok tudós volt, oktatással is foglalkoztak, iskolákat létesítettek, ezért többek között zoológiai könyveket is gyüjtöttek. A könyvtárban jelenleg megtalálható ilyen tárgyú müveket azonban még nem dolgozták fel. Jelen közleményünkben a 16-18. századból származó zoológiai könyveket mutatjuk be, melyek legtöbbje könyvsorozat, kézikönyv, disszertáció vagy tankönyv, de magas színvonalú összefoglaló, tudományos könyv is található közöttük, mint CONRAD GESSNER, UlisSE ALDROVANDI vagy CARL LINNÉ munkái. Kiemelendő, hogy a könyvek negyede (a magyarországi könyvtárak állományának jelenlegi digitális feldolgozottsága alapján) csak ebben a könyvtárban tálható meg Magyarországon. Ez annak a jele, hogy a szakkönyvtárakon kívül egyházi könyvtárakban is értékes zoológiai könyvállományra bukkanhatunk.
\end{abstract}

Kulcsszavak: LINNÉ, BORKHAUSEN, állatrendszertan, tudománytörténet

\section{Bevezetés}

Dolgozatunkban a Pannonhalmi Főapátsági Könyvtár 16-18. századból származó zoológiai könyveit mutatjuk be, kiegészítve BAKONYI \& BAKONYI (2016) könyvtártörténeti munkáját a zoológiai vonatkozásokkal. A témát interdiszciplináris megközelítéssel kezeljük. Célunk elsősorban az, hogy a zoológia tudománytörténetével foglakozó szakemberek számára közelebb hozzuk a Pannonhalmi Főapátsági Könyvtárban rejlö értékeket és ráirányítsuk ezekre a figyelmet, követve a már DURY (1650) által is hangoztatott elvet, miszerint a könyvtárat közel kell vinni az olvasóhoz, a felhasználóhoz. A zoológia történetét kutatók neve megtalálható többek között a BAKONYI et al. (2003) által publikált névjegyzékben, illetve GAZDA (2009) zoológiatörténeti munkákat tartalmazó könyvében. Mivel egy zoológus nagy valószínüséggel nem egyházi könyvtárban keres szakirodalmat, ez a bemutatás felhívhatja a szaktudósok figyelmét a kiválasztott könyvtár anyagára. Érdekes lehet dolgozatunk

* Elhangzott az Állattani Szakosztály 1034. ülésén, 2016. október 5-én. 
továbbá olyan zoológiai szakterületen dolgozó kollégák számára is, akik valamelyik tudományos állítás eredetére kíváncsiak és ehhez forrásokat keresnek. Az állatok elnevezésével kapcsolatos történeti tények sok zoológus kutatót, tudománytörténészt és művelődéstörténészt is érdekelnek. Összefoglaló, újabban megjelent munka a témában például RÁCZ (2012) enciklopédiája. Mivel a tárgyalt korszak könyveiben sok mitikus állat leírása is megjelenik, ez felkeltheti művészek figyelmét is (például SzEMADÁM 1991). Tudománytörténeti forráskiadványok megjelentetésével foglalkozó szervezetek, mint például a Palimpszeszt Kulturális Alapítvány érdeklődésére is számot tarthat ez a dolgozat, ahogy ez az említett alapítvány által megjelentetett müből is kiderül (KÁDÁR \& LADÁNYI-TURÓCZY 2001). Természetszerúleg érdekelheti ez a munka azokat a könyvtári szakembereket, akik régi könyvekkel foglalkoznak és azokat is, akik az ország könyvállományának mind pontosabb feltérképezését végzik. Megpróbáljuk továbbá a feldolgozott anyagot olyan kontextusba helyezni, amely támpontot adhat arra, hogy a Pannonhalmi Föapátsági Könyvtár adott korszakból származó egyes zoológiai könyvei vagy a könyveinek együttese mennyire értékes, különleges, egyedülálló az országon belül. Az anyag nemzetközi összehasonlítása azonban meghaladná a dolgozat kereteit.

A Pannonhalmi Főapátsági Könyvtár Magyarország legrégebbi könyvtára (RÉCSEY 1904), fordulatos történettel, de ennek ismertetése most nem feladatunk. TIBOLD (1999) könyve ad részletesebb információkat a kérdésről. A jelenlegi könyvtári állományt a rend 1802-es visszaállítása után kezdték gyüjteni. A könyvtárban megtalálható zoológiai könyvek eredetéről keveset tudunk. Nem is feladatunk ezek eredetének (proveniencia) megállapítása, csupán néhány utalásszerü történeti megjegyzést teszünk. A rend 1802. évi visszaállítása után mindössze 616 (KISS 1996), más forrás szerint 757 (TIBOLD 1999) könyv került vissza a pannonhalmi könyvtárba. A jelentős gyarapítás után (adományokból, a szerzeteseknek ajándékozott könyvállományokból, máshol felszámolt rendházak könyvtárainak átvétele által, vásárlások során) 1999-re mintegy 250-260 ezer kötet volt a könyvtárban (TIBOLD 1999).

\section{Módszerek}

Vizsgálódásunk kezdő időpontjának a 16. század elejét választottuk, mert a korábban megjelent könyvekben található zoológiai ismeretek jelentős mértékben filozófiai, teológiai okfejtésekhez kötöttek, a természeti megfigyelések, kísérletes adatok, ellenőrzött információk felhasználása kevésbé volt előtérben, ezért ezekkel nem foglalkozunk. Európában a mai értelemben vett természettudományos szemlélet a 16. század közepétől kezdte átvenni a természetismeret helyét, olyan kiemelkedő személyiségek munkáival, mint GESSNER és ALDROVANDI, vagy a speciális területeket érintő, modern szemléletü monográfiákat publikáló BELON (1555), RONDELET (1554) és SALVIANI (1554). Keresésünk végpontja, a 18. század vége. Ennek praktikus oka van. A könyvtárban található, 19. századi zoológiakönyvek száma az előző évszázadokban kiadott hasonló témájú könyvekhez viszonyítva jelentősen megnőtt. Ezek vizsgálata meghaladná jelen tanulmány kereteit.

Feldolgozásunkban azok a művek szerepelnek, amelyek az állatok rendszertanával (taxonómia), fajleírásokkal, csoportjellemzésekkel, a fajok elterjedésével (biogeográfia), az 
állatok evolúciójával, biológiai, viselkedési, ökológiai megfigyelésekkel, vizsgálatokkal, illetve az állattan oktatásával foglalkoznak. A zoológia témaköre jelentősen átalakult az utóbbi mintegy ötven évben, újabb tudományterületek megjelenésének és különböző résztudományos eredmények ugrásszerü növekedésének köszönhetően. Ezért ebben a dolgozatban azokat a jelenleg általánosan elfogadott témaköröket tekintjük a zoológia területébe tartozóknak, amelyek például BAKONYI (2003) tankönyvében is megtalálhatóak. Listába vesszük a nagy kézikönyveket, lexikonokat és tudománynépszerüsítő könyveket is, amelyekben jelentős mennyiségü zoológiai információt találunk. Nem foglalkozunk az állatorvosi, mezőgazdasági, vadászati vagy - jelentős számban található - zoológiai kérdéseket is érintő, de alapvetően természetfilozófiai, vallásfilozófiai müvekkel.

Csak azokat a könyveket tárgyaljuk, amelyeket kézbe is vettünk. Nem teszünk különbséget eredeti munka, fordítás és kompiláció között. Ennek az az oka, hogy a vizsgált korszakban, föleg annak elején, gyakori és elfogadott volt a saját megfigyelésekkel, gondolatokkal kiegészített kompiláció. GESSNER és ALDROVANDI hatalmas munkái is jelentős mennyiségü más müből kivonatolt anyagot tartalmaznak. A fordítások esetén bevett gyakorlat volt, hogy a fordító helyenként átírta, továbbfejlesztette az eredeti anyagot.

A dolgozat végén adjuk közre az általunk kézbe vett könyvek listáját. Az itt közölt könyvjegyzék és a Pannonhalmi Főapátsági Könyvtár katalógusában található adatok között eltérések lehetnek, de a jelen dolgozat végén szereplő listában található adatok frissebbek, mint a könyvtári katalógusokban találhatók, valamint általunk ellenőrzöttek (néhány esetben SAMODAI ÉVA könyvtáros volt szíves ellenőrizni adatainkat).

A szerzők neveit lehetőség szerint a CERL (Consortium of European Research Libraries) Thesaurus adatbázisában megadott egységesített névalak szerint közöljük. A CERL az európai kutató könyvtárak közös projektje, amelynek célja, hogy támogassa a nyomtatott és kéziratos anyagok megosztását a könyvtárak között, és elősegítse ennek a kulturális örökségnek a hasznosítását és megőrzését. (Honlapjának címe a következő: CERL http://thesaurus.cerl.org/) Ha egy szerző neve két vagy több egyenrangú formában szerepel az adatbázisban, vagy egyáltalán nem található meg ott, akkor a könyvön feltüntetett vagy ahhoz az adatbázisban megtalálható, formailag legközelebb eső nevet adjuk meg. A keresztnevek rövidítéseit feloldjuk az egységes megjelenés érdekében, még akkor is, ha a könyvön csak a kezdőbetűk szerepelnek. Fordítások esetében gyakori, hogy a szerző nevét a kiadás nyelvének szabályai szerint írják (pl. a francia származású BONNET, CHARLES neve a német kiadáson BONNET, KARL néven jelenik meg). Ezekben az esetekben a könyvek listájában az eredeti nevet használjuk, hogy csökkentsük a tévedések lehetőségét.

A kiadás helyét úgy adjuk meg, ahogy a könyvön szerepel. A könyv terjedelme mellett a mü méretét is közöljük, továbbá a könyvtári katalógus adatait, ahol lehetett, kiegészítettük a nyomda/kiadó nevével, valamint minden esetben a müfaji kategória szerinti besorolással, a következők szerint (egy könyvet többféle müfajhoz is soroltunk, ha tartalma ezt kívánta):

Z: zoológia, tudományos (kielégíti a szaktudományos könyv kritériumait az adott kor színvonalának megfelelően; lehet átfogó mü, lexikon, vagy speciális területet tárgyaló szakkönyv), Z,T: zoológia és teológia (zoológiai adatok, ismeretek felhasználása filozófiai, teológiai érvelésben, de a zoológiai leírások kielégítik a kor szaktudományos kritériumait és nem csupán illusztrációt, vagy spekulációt jelentenek), N: tudománynépszerüsítő, ismeret- 
terjesztő könyv, T: gimnáziumi tankönyv, D: disszertáció (doktori vagy akár alacsonyabb szintü szaktudományos dolgozat).

Sorozatok esetében csak azokat a köteteket vettük fel a listára, amelyek részben vagy egészben zoológiai témájúak, de a sorozatok egyéb témájú köteteit értelemszerüen nem vettük figyelembe, ugyanis többször előfordult, hogy például a botanika és a mineralógia témaköre is szerepelt a zoológiával foglalkozó kötetek mellett egy sorozaton belül. Voltak továbbá olyan könyvek is, amelyekben mind a három említett témakör egybekötve szerepelt. Ekkor a könyvet a zoológiai könyvek között soroljuk fel annak ellenére, hogy csak egy része tekintendő témánkba vágónak. A dolgozatunk végén található könyvek listájában mindegyik tétel önálló sorszámot kapott, amelynek segítségével egyértelmủen azonosítani lehet a kötetet.

Az 1750-es évekig szinte kizárólag latin nyelvü könyvek találhatóak a listán. Ezután egyre nagyobb számban jelennek meg a német nyelvüek és ezek veszik át a vezető szerepet. Kevés francia, angol és olasz nyelvü könyv van az áttekintett időszakból a Pannonhalmi Főapátsági Könyvtárban. Magyarul csak a vizsgált időszak utolsó két évében jelentek meg zoológiai könyvek. GÁTI népiskolai tankönyve két kiadásban és RAFF könyvének magyar fordítása található meg a könyvtárban. RAFF könyvét FÁBIÁN JÓZSEF fordította és egészítette ki. A két könyvről FEHÉR (2000) és Sz. KRISTÓF (2012) tanulmányaiban találhatók részletes információk.

Áttekintést végeztünk továbbá arra vonatkozóan is, hogy a vizsgált korszak jelentős zoológusai közül kinek a müve(i) található meg jelenleg a könyvtárban. A módszerünk a következő volt: három zoológiatörténeti könyvből (BURCKHARDT 1907, CARUS 1872, LANKESTER 1893), kigyüjtöttük a 16-18. századi jelentős zoológusok neveit. Heten szerepeltek mind a három könyvben (ULISSE ALDROVANDI, BUFFON - eredeti nevén GEORGES-

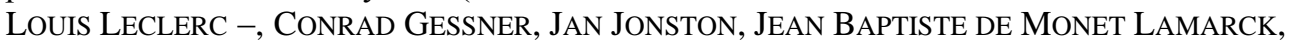
CARL LINNÉ, JOHN RAY). RAY kivételével mindegyik szerzőnek van egy vagy több könyve a könyvtárban. Öten szerepeltek a három könyv közül legalább kettőben (PIERRE BELON, Martin Lister, Albertus Magnus, René Antoine Ferchault de RÉaumur, Edward WOTTON). Közülük MAGNUS és WotTON müvei találhatóak meg Pannonhalmán. Mindezek alapján azt mondhatjuk, hogy a korszak fontos zoológusainak műveit érdemes a Pannonhalmi Főapátsági Könyvtárban keresni, mert viszonylag sok mü található meg egy helyen.

\section{Áttekintés és diszkusszió}

Összesen 150 kötetet tekintettünk a bemutatott módszertani szempontok szerint zoológiai témájúnak. A könyvek típus szerinti megoszlását az 1. táblázat mutatja be. A táblázat adataiból az derül ki, hogy aránylag sok a sorozat és a kézikönyv. Ez nem csoda, hiszen a tudós tanárok elöször ezekhez a müvekhez nyúltak, ha egy információt meg akartak szerezni. Figyelemre méltó azonban a szakkönyvek relatíve nagy aránya. Véleményünk szerint a tudománynépszerüsítő könyvek száma ismertségük, elterjedtségük és könnyü hozzáférhetőségük miatt magas. A gimnáziumi tankönyvek az 1700-as évek vége felé jelentek meg. Nem véletlenül. A rend 1802-es visszaállítása után I. FERENC magyar király az oktatást, a 
fiatalság nevelését és képzését is feladatul szabta a bencéseknek. Ettől kezdve Pannonhalmának a teológiai képzés mellett középiskolai tanári képzést is kellett végeznie (MÉSZÁROS 1990).

1. táblázat. A Pannonhalmi Főapátsági Könyvtárban talált zoológiai könyvek típus szerinti megoszlása (kötetek száma alapján).

Table 1. Categories of the zoology books in the Library of the Archabbey of Pannonhalma according to their content.

\begin{tabular}{|c|c|c|}
\hline Típus & Kötetek száma (db) & Megjegyzés \\
\hline Könyvsorozat & 73 & \\
\hline Kézikönyv & 28 & $\begin{array}{l}\text { gyakran az ásványokat és } \\
\text { növényeket is tartalmazza }\end{array}$ \\
\hline Speciális szakkönyv & 20 & egy részterület feldolgozása \\
\hline Zoológia és teológia & 6 & $\begin{array}{l}\text { teológiai megfontolások, erős } \\
\text { zoológiai adatokkal }\end{array}$ \\
\hline Tankönyv & 14 & gimnáziumi tankönyv \\
\hline Tudománynépszerüsítő & 7 & ebből négy kötet egy sorozat része \\
\hline Disszertáció & 2 & önálló könyvfejezetként \\
\hline
\end{tabular}

A könyvsorozatok legrégebbi és legismertebb darabjai CONRAD GESSNER és ULISSE ALDROVANDI hatalmas, enciklopédikus müvei, amelyekben rendszeres, sok tekintetben kritikus, máshol azonban az általánosan elfogadott, de ma már tévesnek bizonyult állításokat is elfogadva írták meg monumentális munkáikat (RIEDL-DORN 1989). A két tudós zoológiai munkásságát itt nem értékeljük, mert ez meghaladná e közlemény célját és terjedelmét. Azok számára, akik részletesebb információt keresnek a témáról GESSNER esetében utalunk FisCHER (1966), LEY (1929) és PINON (2005) müveire. ALDROVANDI - témánkba vágó könyveiről újabban VISKOLCZ (2014) írt összefoglalót. Kiemeljük, hogy mindkét szerző munkáiban képzőmüvészeti szempontból is igen érdekes és értékes ábraanyag található, állatábrázolással foglalkozó müvészeknek javasolt ismeret (DELFINO \& CEREGATO 2008, KUSUKAWA 2010) (1. ábra).

Az előzőekhez hasonlóan, és az említett okok miatt, nem foglalkozunk LINNÉ legismertebb munkájának, a Systema Naturae címünek köteteivel sem. Megfelelő áttekintést és értékelést sok helyen találunk (például SZABÓ 2008, MÜLLER-WILLE 2013). JONSTON széles körben elterjedt, népszerü ötkötetes sorozata (emlösök, madarak, ízeltlábúak, kétéltűek és hüllök, halak és cetek) teljes a könyvtárban. Az illusztrációk ezekben a könyvekben is müvészi értéket képviselnek (MATUSZEWSKI 1989). JONSTONHOZ hasonló, élvezetes stílusban írt BUFFON, akinek szintén több nyelvre is lefordították a müveit. Munkásságát ROGER (1997) foglalta össze. BUFFON müvei közül egy emlősökről szóló 13 kötetes (négykötetnyi ábrával kiegészített) és egy madarakról szóló nyolckötetes (egy kötetnyi ábrával kiegészített) sorozat található meg a könyvtárban. Zoológiai szempontból de BEAURIEU és HENNEBERT hét kötetből álló könyvsorozata kevésbé érdekes, mert tudomány és morál keveredik a szövegben. MARTINI 11 kötete valódi, mai értelemben vett lexikon, ahol a címszavak alfabetikus sorrendben követik egymást. Nem csupán zoológiai, hanem a kor szoká- 
sához híven, botanikai és mineralógiai szakkifejezéseket is tartalmaz. A bemutatott sorozatok zoológiai szempontból átfogják a korszak tudományos ismereteit.
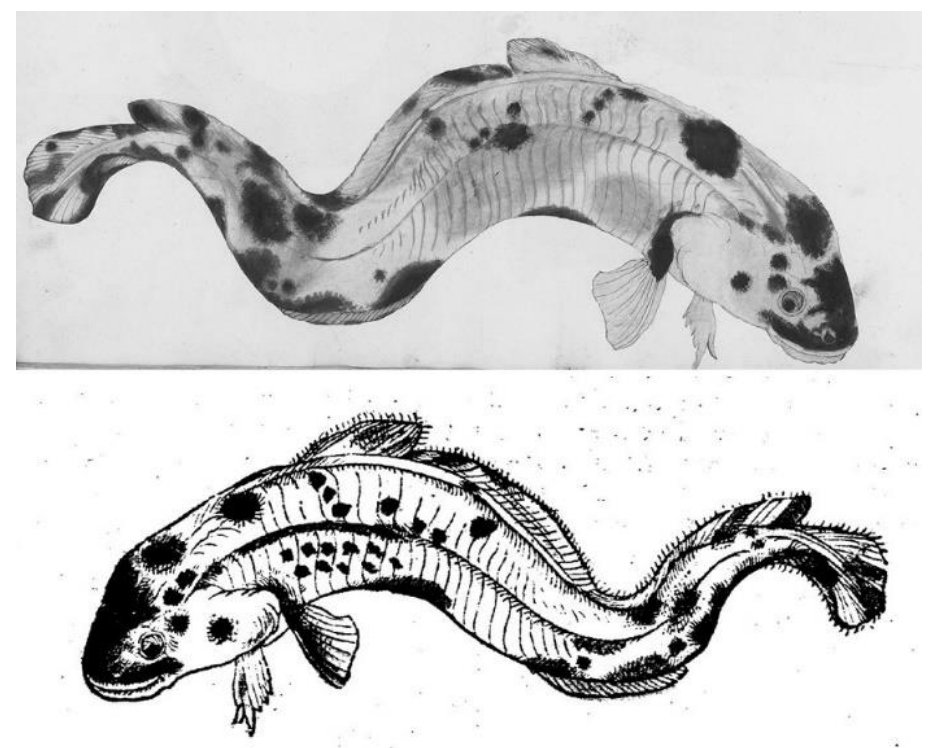

1. ábra. Az igen ritkának számító menyhalról (Lota lota) készült 16. századi festmény (fenn) és ahogy GESSNER könyvében, mint fametszet megjelent (lenn). Az eredeti kép színes volt. A gazdag olvasóknak készült kötetekben a fametszeteket kézzel kiszínezték.

Figure 1. The 16th century painting of a rare burbot fish (Lota lota) (upper) and as a woodcut in GESSNER's book. The original painting was colored. The woodcuts were also colored in the copies made for wealthy readers.

A zoológiai kézikönyvek egy csoportjában a könyvek rendszerint zoológia, botanika és mineralógia fejezetekre tagolódnak, sokszor ebben a sorrendben. A legnagyobb fejezet mindig a zoológia, tekintettel az állatfajok és a hozzájuk kapcsolódó ismeretek számos voltára. A vizsgált időszak utolsó negyedszázadában jelennek meg azok a kézikönyvek, amelyek már csak általános természettörténeti és zoológiai ismereteket tartalmaznak, botanikai és mineralógiai fejezetek nélkül. Ez jelzi a speciális ismeretek mennyiségének jelentős növekedését. A kézikönyvek közül kiemelendő SPERLING (1661) müve (2. ábra), amelyben például a fejtetủ biológiájáról máig idézhető adatokat közöl (MEY 2003). A fajok (csoportok) meglepően korrekt, didaktikus, müvelődéstörténeti és filozófiai megjegyzésekkel tarkított leírását alkalmazza, ezért érdemes két példát alaposabban is bemutatni. A tủzmolyokhoz (Pyraustidae) tartozó Pyrausta genusz elnevezéssel a lepkéket (A pillangóról), Musca elnevezéssel a legyeket jellemzi (A légyröl), egységes szerkezet szerint. Részletek a szövegböl:

„A pillangóról. Tanitás: A pillangó nagyon törékeny rovar, amely jelzi a tavaszt és kedveli a virágokat. Kérdések: I. Mivel táplálkozik? Válasz: A pillangó, németül SommerVogel (sic!) vagy MolckenDieb (sic!), keveset táplálkozik, leginkább a virágokból. Szereti ugyanis a virágokat, és ezekböl szívja ki mindazt, ami inyére van. II. Hogyan növekedik? Válasz: 
Mérete és felépitése változatos, mivel száznál többfélét ismerünk. A legtöbbjüknek csápjaik és törékeny, lisztszerü porral behintett szárnyaik vannak, amelyek közül némelyik foltot visel, némelyik egyszinü. Magukat a lepkéket pedig hol egy, hol kettö, hol több szín alapján határozzuk meg. III. Hogyan szaporodnak? Válasz: Párosodnak és petét raknak. Úgy tartják róluk, hogy fákból, férgekböl és másokból születnek. De azt, amit gyakran mondanak, gondolkodással kell értelmezni. Ami fákban, levelek között, rothadó dolgokban lesz, nem egyenesen azokból keletkezik. Alaptétel: Néhány pillangó a fényre repül. A pyrausta, görögül pürausztész, tömeges rovar, azt tartják róla, hogy a tüzben születik, de egyetlen élölénynek sem lehet ilyen születése. Egyes pillangókat megbabonáz a tüz fénye, és a tüzbe repülnek majd elégnek. Tehát ezeket tartjuk a valódi pyraustáknak. Innen való a közmondás, a pyrausta halála, arról az emberröl, aki a saját vesztébe rohan. És a pyrausta örömének örül, a pillanatnyi gyönyörüségröl, amit örök szerencsétlenség követ." (BíRÓ CsILLA fordítása.)

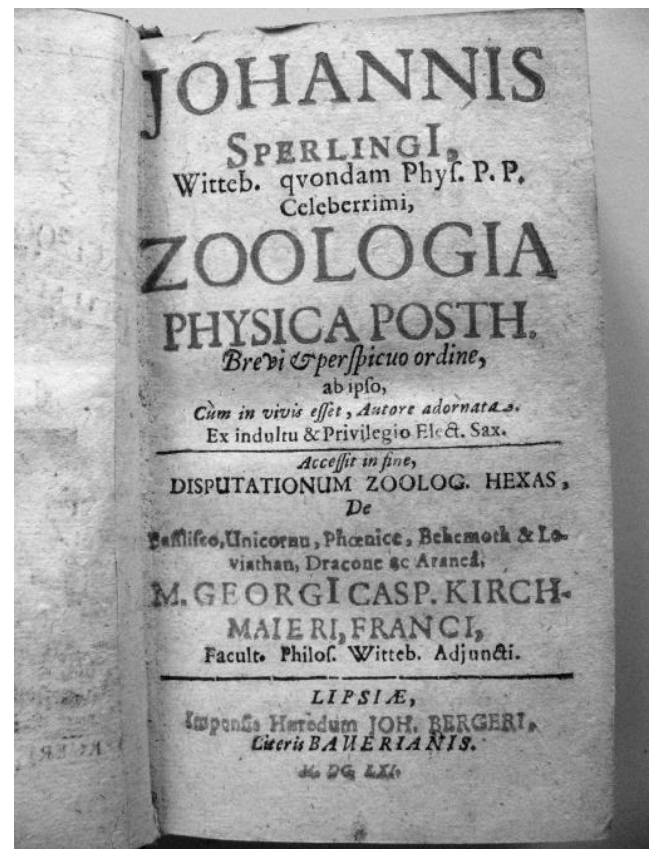

2. ábra. SPERLING könyvének címlapja.

Figure 2. Cover page of SPERLING's book.

„A légyröl. Szabály. A légy bosszantó, szemtelen, arcátlan, tolakodó, nyugtalan rovar. Kérdések: I. Mivel táplálkozik? Válasz: A legyek szinte mindent megkóstolnak, minden után sóvárognak, leginkább pedig a vér iránt epekednek. A légy az ember evötársa, lakótársa, asztaltársa. Bárhol teritett asztala van, a szegények kunyhóiban éppen úgy, mint a királyok és hercegek váraiban és palotáiban. Amit a szakácsok az ö zúgása mellett füszereznek, azt megkóstolja, még magukat az urakat is megelözve. Söt, megtámadja az urakat, és velük 
küzdve még zaklatja is őket, és miután azok elkergetik, annál inkább visszatér, és miután újra és újra elüzik, jobban és jobban törekszik visszajönni. II. Hogyan növekedik? Válasz: Nagyságra és felépitésre nézve változatos. Egyesek mérete ugyanis igen kicsi, egyeseké közepes, másoké nagyobb. Némelyik feje nagy, némelyiké kicsi; Valamelyik potroha vastag, némelyik a homlokán vékony csápokat vagy szarvacskákat visel, némelyiknek ez hiányzik. Ormányuk van, amellyel mindent megérintenek és felfalnak. Van szárnyuk, de nem olyan, mint a madaraké, hanem hártyából van. Mikor azokat a nap(fényben) kiterjesztik, különbözö szinekben pompáznak, szépségük vetekszik a páva farkával. III. Hogyan szaporodnak? Válasz: Párzást végeznek, és gyakran egyesülve repülnek. A nemzésük adománya (ti. eredménye) a pete, amelyből elöször lárva lesz, majd pedig a légy. Scaliger ezt mondja: Pontosabban itélné azt, hogy a tojás több mint a pete. És ugyan minden közbeesés nélkül a petéböl tüstént állat születik: némelyik esetben másként történik. A petéböl ugyanis nem azonnal állat lesz, hanem valami közbülsö (ti. átmeneti). E közbülsö dolognak (átmenetnek) két módja van: az egyik befejezettebb, úgymint a legyek lárvái, ivadékai, amelyekböl a legyek lesznek, a másik befejezetlenebb, úgymint a tojások, amely arányainak növényei(?). Nem gondolom tehát gyümölcsmagnak vagy tojásnak, mint amilyen az állat petéje, hanem a pete belsejébe rejtett teljes egész (ti. ép) utódnak, de mégsem izekkel ellátottnak. Befejezettnek mondom minden egyéb tekintetében kivéve az izeket. Ezt a széleskörü véleménnyel ellentétben én úgy gondolom, hogy nem kell durvább (alacsonyabb rendü) természeti sajátosságnak elfogadni. Az olajjal vagy vízzel elpusztitott legyek feltámadnak. Miután elpusztultak, ha sóval vagy hamuval meghintjük öket, a legyek feltámadnak. Így halottak voltak az élet második szakaszáig, de nem az elsöig. Jelen volt a lélek, az élet azokban az elpusztult legyekben, egészen az elsö szakaszig; hiányzott a lélek, az élet a második szakaszig. Így tehát nem annyira halottnak, mint inkább kvázi halott vagy félig halott legyeknek mondják öket. A teljes megfosztástól ugyanis az (élö) állapothoz természetesen nincs visszatérés. A nagyobb legyek ürülékéböl férgek lesznek. A légy tisztátalan állat; ürülékével bemocskolja a padokat, a festményeket, a ruhákat, a könyveket. És nem ritkán abból az ürülékböl, különösen a nagyobbakéból, mindenekelött a húsokra veszélyes férgek kelnek ki. Scaliger látta, hogy a légy a kezében lerakja azt az anyagot, amelyböl a féreg kikel. Ennek a dolognak az oka az emberek számára nem marad homályban. A legyek ugyanis minden után sóvárognak, és a férgek anyagát(?) a táplálékkal együtt elfogyasztják, és az elfogyasztott dolgot a gyomrukon keresztül adják vissza." (SZEBELÉDI ZsOLT fordítása.)

Mindkét jellemzés jól ecseteli a két nagy rovarrend (hiszen lényegében rendek jellemzéséről van szó) morfológiájának, biológiájának és ökológiájának változatosságát. A lepkék esetében a fototaxis jelenségének, a legyek esetében pedig a holometamorfózis megfelelő leírását tartjuk szakmai szempontból értékesnek, hiszen több mint 350 éves szakmai szövegekről van szó. Érdekesek a bölcseleti fejtegetések is, a saját vesztébe rohanó emberről és a legyek feltámadásáról.

A speciális szakkönyvek közül csak azokat emeljük ki, amelyek a kor általános szaktudományos színvonalát meghaladják, esetleg máig érvényes eredményeket tartalmaznak. A faunisztikai és taxonómiai kötetek közül érdekes Kühn könyve, amely a rovargyüjtés módszereivel foglalkozik. KRAMER, a lápi póc (Umbra krameri) névadója, Alsó-Ausztria flóráját és faunáját dolgozta fel. VON PAULA SCHRANK szintén Ausztriából publikált magas szintü faunisztikai munkát. VON NEUHAUS számos új faj, máig érvényes leírását közli. BORKHAUSEN munkája a lepke-taxonómusok számára ma is alapmü. Ökológiai ismereteket 
is tartalmaz VON GLEICHEN tetszetős illusztrációkkal díszített munkája, amely a szilfákon élő levéltetvekről és ragadozóikról szól, valamint SCHOENBAUERnek a kártevő kolumbácsi légy (Simulium colombaschense) fajról írt könyve. A hidrobiológiai könyvek közül említésre méltó EICHHORN szépen illusztrált könyvecskéje a zooplankton egyes fajairól és BLOCH jelentős munkája a németországi halfaunáról.

A tudománynépszerüsítő könyvekre jellemző, hogy a szaktudományos ismeretek mellett sokszor filozófiai és teológiai megfontolásokat is tartalmaznak. Gyakori továbbá, hogy a mai múzeumok egyik elődjét jelentő, vegyes, többé-kevésbé rendezett természettudományi gyüjtemények, az úgynevezett „,csodák kamrája” (Wunderkammer) tárgyait, anyagát is bemutatják. Ezekben a gyüjteményekben a furcsaságok (például csontok, torzult csőrü madarak, ismeretlen eredetü trópusi növények és állatok) domináltak részletes, alapos tudományos feldolgozás, háttér nélkül.

A tankönyvek közül a legelterjedtebb PILLER (1778) munkája volt, amit gimnáziumi tanulók számára írt, természetesen latin nyelven. Ebben a tankönyvben már komoly szakmai anyag szerepel. A rovarok rendszertanát tekintve például hét nagy csoport ismerete volt kötelező. Ezek a következők: I. Coleoptera, II. Hemiptera, III. Lepidoptera, IV. Neuroptera, V. Hymenoptera, VI. Diptera, VII. Aptera. Meg kellett tanulni a csoportokat elkülönítő morfológiai jegyeket és azokat a nagyobb rovarcsoportokat is, amelyek az adott taxonba tartoznak. A II. Hemiptera esetében például három csoportot különböztettek meg; 1. Gryllus (Migratorius, Sáska, Zugheuschrecke), 2. Cicada (Prütsök, Baumgrille, Cicade) és 3. Cimex (Lectularius, Palatzka, Bettwanze). Láthatóan igyekezett minél több nevet megadni a pontos azonosíthatóság kedvéért. PILLER könyvét az első Ratio Educationis (1777) előírása (131. §) miatt készítették (FRIML 1913, MÉSZÁROS 1980), és széleskörüen használták a magyar iskolákban. Ugyanakkor, ahogy ez lenni szokott, tartalmát kritika is érte, és volt, aki jobb tankönyvet kívánt (ACSAY 1898).

Kutatásunk tanulsága, hogy egy olyan speciális témakörben, mint a 16-18. századi zoológia nem elég a nagyobb könyvtárak és szakkönyvtárak anyagának áttanulmányozása, hanem érdemes az egyházi könyvtárak gyüjteményeibe is betekinteni. Mint láttuk, egy olyan rend könyvtárában, mint amilyen a bencés, amely foglalkozott felsőoktatással története során, feltáratlan kincsekre lelhetünk, hasonlóan, ahogy ez a zirci Ciszterci Müemlékkönyvtárban fellelt „Bestiarium Zircense” esetében történt (BORECZKY 2016).

Köszönetnyilvánítás. Köszönjük VÁRSZEGI ASZTRIK föapát úrnak és HORTOBÁGYI CIRILL perjel atyának, hogy kutatásunkat lehetővé tették, valamint ÁSVÁNYI ILONA helyettes igazgatónak és különösen SAMODAI ÉvA könyvtárosnak készséges segítségét a könyvtári munkában. Köszönettel tartozunk továbbá VARGA BERNADETTnek (Országos Széchényi Könyvtár, Régi Nyomtatványok Tára) a kézirat elkészítése során nyújtott értékes szakmai tanácsaiért, BíRó CsILLÁnak és SzEBELEDI ZsolTnak (Országos Széchényi Könyvtár, Régi Nyomtatványok Tára) a pillangóról és a légyről szóló szöveg nem kevés fáradsággal járó fordításáért. Dr. Korsós ZolTÁN és Dr. VíG KÁROLY alapos lektori munkáját ezen a helyen is köszönjük. 


\section{Irodalomjegyzék}

ACSAY, F. (1898): Értesitő a pannonhalmi Sz.-Benedek-rend Győri Fögimnáziumáról az 1897-98. isk. év végén. Győregyházmegye Sajtója, Győr, 320 pp.

BAKOnYI, G. (szerk.) (2003): Állattan. Mezőgazda Kiadó, Budapest, 699 pp.

BAKONYI, G., Kiss, I. \& SERES A. (2003): A magyar zoológusok névjegyzéke. Állattani Közlemények 88: $117-148$.

BAKONYI, G. \& BAKONYI, Zs. (2016): A Pannonhalmi Főapátsági Könyvtár zoológiai könyvei a 1618. századból. Magyar Könyvszemle 132(4): 463-478.

BeLON, P. (1555): L'Histoire de la nature des oyseaux. Paris, $381 \mathrm{pp.}$

BoreCZKY, A. (2016): Bestiarium Zircense. Országos Széchenyi Könyvtár, Budapest, 75 pp.

BURCKHARDT, R. (1907): Geschichte der Zoologie. Göschen, Leipzig, 156 pp. https://doi.org/10.5962/bhl.title.22954

CARus, J.V. (1872): Geschichte der Zoologie bis auf Johannes Müller und Charles Darwin. Oldenbourg Verlag, München, 739 pp. https://doi.org/10.5962/bhl.title.1933

Delfino, M., \& Ceregato, A. (2008): Herpetological iconography in the 16th century: the tempera paintings of Ulisse Aldrovandi. Bibliotheca Herpetologica 7: 4-12.

DURY, J. (1650): The Reformed Library-Keeper. Du-Gard, London, 65 pp.

Friml, A. (1913): Az 1777-iki Ratio Educationis. Kath. Középiskolai Tanáregyesület, Stephaneum, Budapest, $271 \mathrm{pp}$.

GAZDA, I. (2009): Bevezetés a reáltudományok történetének magyarországi könyvészetébe. Hatágú Síp Alapítvány, Budapest, 214 pp.

FEHÉr, K. (2000): Első magyar nyelvü illusztrált tankönyveink. In: JÁKI L. (szerk.): Orbis Pictus. A szemléltetés évszázadai. Országos Pedagógiai Könyvtár és Múzeum, Budapest, pp 72-81.

FISCHER, H. (1966): Conrad Gessner (26 März 1516-13 December 1565): Leben und Werk. Kommissionsverlag Leeman, Zurich, $152 \mathrm{pp}$.

KÁDÁR, Z. \& LADÁNYI-TuRÓCZY, Cs. (szerk.) (2001): Isten állatkertje. Válogatás a középkor és a reneszánsz állatleírásaiból. Palimpszeszt Kulturális Alapítvány, Budapest, 228 pp.

KIss, D. (1996): Régi magyarországi könyvek a pannonhalmi Szent Benedek-rendi Főkönyvtárban az 1786-os aboliciós katalógus alapján. Pannonhalmi Füzetek 38. Pannonhalma, 107 pp.

Kusukawa, S. (2010): The sources of Gessner's pictures for the Historia animalium. Annals of Science 67: 303-328. https://doi.org/10.1080/00033790.2010.488899

LANKESTER, E. R. (1893): The History and Scope of Zoology. Humboldt Publishing Company, New York, $58 \mathrm{pp}$.

LEY, W. (1929): Konrad Gesner: Leben und Werk. Verlag d. Münchner Drucke, München, 154 pp.

Matuszewski, A. (1989): Jan Jonston-Outstanding Scholar of the 17th Century. Studia Comeniana et Historica 19: 37-53.

Mey, E. (2003): On the development of animal louse systematics (Insecta, Phthiraptera) up to the present day. Rudolstädter Naturhistorische Schriften 11: 115-134.

MÉszÁros, I. (1980): Az 1777-i és az 1806-i Ratio Educationis tankönyvei. Magyar Könyvszemle 96 : 350-369. 
MÉszÁros, I. (1990): Iskola Szent Márton hegyén. A Pannonhalmi Bencés Gimnázium története. Pannonhalma, 147. pp.

MÜLLER-WILlE, S. (2013): Systems and how Linnaeus looked at them in retrospect. Annals of Science 70: 305-317. https://doi.org/10.1080/00033790.2013.783109

PILlER, M. (1778): Elementa Historiae Naturalis in usum scholarum grammaticarum et gymnasiorum per regnum Hungariae et provincias eidem adnexas. Pars I. Complectens Regnum Animale. Typis Regiae Universitatis, Budae, 60 pp.

PINON, L. (2005): Conrad Gessner and the historical depth of Renaissance natural history. In.: PomatA, G. \& SiRAisi, N. G. (eds.): Historia: Empiricism and erudition in early modern Europe. MIT Press, Cambridge, pp. 241-267.

RÁCZ, J. (2012): Állatnevek enciklopédiája. A gerincesek elnevezéseinek eredete, az állatok kultúrtörténete, néprajza és mitológiája. Tinta Könyvkiadó, Budapest, 548 pp.

RÉCSEY, V. (1904): Ösnyomtatványok és régi magyar könyvek a pannonhalmi könyvtárban. „Hunyadi Mátyás" Irodalmi és Könyvnyomdai Intézet, Budapest, 486 pp.

RIEDL-DORN, C. (1989): Wissenschaft und Fabelwesen: ein kritischer Versuch über Conrad Gessner und Ulisse Aldrovandi. Boehlau Verlag, Wien, 183 pp.

Roger, J. (1997): Buffon: A life in natural history. Cornell University Press, Ithaca, 492 pp.

RONDELET, G. (1554): Libri de piscibus marinis in quibus verae piscium effigies expressae sunt. Bonhomme, Lyon, 583 pp. https://doi.org/10.5962/bhl.title.64229

SALVIANI, I. (1554): Aquatilium animalium historiae. Hippolytum Salvianum, Romae, 265 pp.

SPERLING, J. (1661): Zoologia physica posthuma. Berger, Lipsiae, 466 pp.

SzABÓ, T. A. (2008): Carolus Linnaeus (1707-1778), a Linné-emlékév (2007) és a "bioinformatika" kezdetei. Magyar Tudomány 169: 952-967.

SzemadÁm, Gy. (1991): Apokrif állattan. Móra Kiadó, Budapest, 147 pp.

Sz. KRISTÓF, I. (2012): „Szep, majom, fekete ember, matska kepeket mutat neki”: a természethistória színtereinek textuális és figurális konstrukciója G. C. Raff tankönyvében, 1778/1799-1846. In: GuRKA, D. (szerk.): Tudósok a megismerés szinterein. A romantikus tudományok és a 18-19. századi tudóssztereotípiák. Gondolat, Budapest, pp. 160-176.

TiBold, G. A. (1999): A pannonhalmi könyvtár története: különös tekintettel annak fejlödésére 1802től napjainkig (sajtó alá rend. Somorjai Ádám). Pannonhalmi Füzetek 45. Pannonhalma, 117 pp.

VISKOLCZ, N. (2014): Ulisse Aldrovandi müveinek összkiadása a 17. századból az SZTE Klebelsberg Könyvtárban. Magyar Könyvszemle 130: 163-179. 


\section{Függelék}

\section{A Pannonhalmi Főapátsági Könyvtárban található, 16-18. századi zoológiai könyvek listája}

A könyvek sorszáma után pontosvesszővel elválasztva közöljük a következő információkat: szerző, cím, megjelenés helye, kiadó, kiadás éve, oldalszám (szögletes zárójelben a számozatlan oldalak száma), rét-nagyság, müfaji kategória.

*: Magyarországon csak ebben a könyvtárban található kötet.

1.) Aldrovandi, Ulisse: De animalibus insectis. Francofurti, Hoferi, 1623. [10], 299, [22] p., $2^{\circ}-\mathrm{Z}$

2.) AldRovandi, Ulisse: De reliquis animalibus exanguibus. Francofurti, Hoferi, 1623. [6], 192, [16] p., $2^{\circ}-\mathrm{Z}$

3.) Aldrovand, Ulisse: De quadrupedis solidipedibus. Volumen Integrum, Francofurti, Hoferi, 1623. [8], 223, [4] p., $2^{\circ}-\mathrm{Z}$

4.) Aldrovandi, Ulisse: De piscibus Libri V. et de cetis Liber I. Francofurti, Treudel, 1634. [16], 280, [40] p., $2^{\circ}-\mathrm{Z}$

5.)* Beaurieu, Gaspard Guillard de, Hennebert, Jean Baptiste François: Cours D'Histoire Naturelle, Ou Tableau De La Nature: Considérée dans l'Homme, les Quadrupédes, les Oiseaux, les Poissons \& les Insectes. Paris, Desaint, 1770. [4], 466, [6] p., $12^{\circ}-\mathrm{Z}$

6.)* Beaurieu, Gaspard Guillard de, Hennebert, Jean Baptiste François: Cours D'Histoire Naturelle, Ou Tableau De La Nature: Considérée dans l'Homme, les Quadrupédes, les Oiseaux, les Poissons \& les Insectes. Paris, Desaint, 1770. [4], 488, [4] p., $12^{\circ}-\mathrm{Z}$

7.)* Beaurieu, Gaspard Guillard de, Hennebert, Jean Baptiste François: Cours D'Histoire Naturelle, Ou Tableau De La Nature: Considérée dans l'Homme, les Quadrupédes, les Oiseaux, les Poissons \& les Insectes. Paris, Desaint, 1770. [4], 416 p., $12^{\circ}-\mathrm{Z}$

8.)* Beaurieu, Gaspard Guillard de, Hennebert, Jean Baptiste François: Cours D'Histoire Naturelle, Ou Tableau De La Nature: Considérée dans l'Homme, les Quadrupédes, les Oiseaux, les Poissons \& les Insectes. Paris, Desaint, 1770. [4], 317 p., $12^{\circ}-\mathrm{Z}$

9.)* BeAurieu, Gaspard Guillard de, Hennebert, Jean Baptiste François: Cours D'Histoire Naturelle, Ou Tableau De La Nature: Considérée dans l'Homme, les Quadrupédes, les Oiseaux, les Poissons \& les Insectes. Paris, Desaint, 1770. [4], 483 p., $12^{\circ}-\mathrm{Z}$

10.*) Beaurieu, Gaspard Guillard de, Hennebert, Jean Baptiste François: Cours D'Histoire Naturelle, Ou Tableau De La Nature: Considérée dans l'Homme, les Quadrupédes, les Oiseaux, les Poissons \& les Insectes. Paris, Desaint, 1770. [4], 349 p., $12^{\circ}-\mathrm{Z}$

11.)* Beaurieu, Gaspard Guillard de, Hennebert, Jean Baptiste François: Cours D'Histoire Naturelle, Ou Tableau De La Nature : Considérée dans l'Homme, les Quadrupédes, les Oiseaux, les Poissons \& les Insectes. Paris, Desaint, 1770. [4], 317 [2] p., $12^{\circ}-\mathrm{Z}$

12.*) Beckmann, Johannes: Anfangsgründe der Naturhistoriae. Frankfurt und Leipzig, s.n., 1777. 276 p., $8^{\circ}-\mathrm{Z}$ 
13.)* BeSLER, Michaeleis Rupert: Gazophylacium rerum naturalium Regno Vegetabili, Animali \& Minerali depromtarum, nunquam hactenus in lucem editarum. Lipsiae and Francofurti, Klosium, 1716. [4], 35 p., $2^{\circ}-\mathrm{Z}$

14.) BLOCH, Marcus Elieser: Oeconomische Naturgeschichte der Fische Deutschlands. 1. Theil., Berlin, s.n., 1782. [16], 258 p. $4^{\circ}-\mathrm{Z}$

15.) BlumenBach, Johann Friedrich: Handbuch der Naturgeschichte. Göttingen, Dieterich, 1779. [12], 559, [32] p., $8^{\circ}-\mathrm{Z}$

16.) BlumenBaCH, Johann Friedrich: Handbuch der Naturgeschichte. Göttingen, Dieterich, 1782. [8], $561,[26]$ p., $8^{\circ}-\mathrm{Z}$

17.) BlumenBaCH, Johann Friedrich: Handbuch der Naturgeschichte. Göttingen, Dietrich, 1799. 16, 708, [36] p., $8^{\circ}-\mathrm{Z}$

18.)* BOEHMER, Georg Rudolph: Systematisch-Literaerisches Handbuch der Naturgeschichte Oeconomie und anderer damit verwandten Wissenschaften und Künste. Zweyter Theil Thierreich Erster Band., Leipzig, Iunius, 1786. [4], 604 p., $8^{\circ}-\mathrm{Z}$

19.)* Boenmer, Georg Rudolph: Systematisch-Literaerisches Handbuch der Naturgeschichte Oeconomie und anderer damit verwandten Wissenschaften und Künste. Zweyter Theil Thierreich Zweyter Band., Leipzig, Iunius, 1786. [2], 536 p., $8^{\circ}-\mathrm{Z}$

20.) Bonnet, Charles: Oeuvres d'histoire naturelle et de philosophie. Neuchatel, Fauche, 1779. [6], 574, [2] p.; $4^{\circ},-\mathrm{Z}, \mathrm{T}$

21.) Bonnet, Charles: Oeuvres d'histoire naturelle et de philosophie 2. Mémoires d'histoire naturelle. Neuchatel, Fauche, 1779. [4], 524, [2] p., $4^{\circ}-\mathrm{Z}, \mathrm{T}$

22.) BonNET, Charles: Betrachtung über die Natur. Erster Band, Leipzig, Junius, 1783. 438 p., $8^{\circ}-\mathrm{Z}$

23.) BonNET, Charles: Betrachtung über die Natur. Zweiter Band, Leipzig, Junius, 1783. 534, [24] p., $8^{\circ}-\mathrm{Z}$

24.)* BorkHAusen, Moritz Balthazar: Naturgeschichte der Europäischen Schmetterlinge nach systematischer Ordnung. Erster Theil: Tagschmetterlinge. Frankfurt, Varrentrapp und Wenner, 1788. 288, [2] p., $8^{\circ}-\mathrm{Z}$

25.)* BorkHAusen, Moritz Balthazar: Naturgeschichte der Europäischen Schmetterlinge nach systematischer Ordnung. Zweiter Theil: Sphinxe, Schwärmer. Frankfurt, Varrentrapp und Wenner, 1789. 239, [4] p., $8^{\circ}-\mathrm{Z}$

26.)* BorkHAuSEN, Moritz Balthazar: Naturgeschichte der Europäischen Schmetterlinge nach systematischer Ordnung. Dritter Theil: der Phalänen erste Horde, die Spinner. Frankfurt, Varrentrapp und Wenner, 1790. [12], 476 p., $8^{\circ}-\mathrm{Z}$

27.) BORKHAUSEN, Moritz Balthazar: Naturgeschichte der Europäischen Schmetterlinge nach systematischer Ordnung. Vierter Theil: der Phalänen zweite Horde: Eulen. Frankfurt, Varrentrapp und Wenner, 1792. 809 p., $8^{\circ}-\mathrm{Z}$

28.) Buffon, Georges-Louis Leclerc: Histoire naturelle des Oiseaux. Tome Premier, Paris, De L'Imprimerie Royale,1770. [6], 352 p., $12^{\circ}-\mathrm{Z}$

29.) BUFFON, Georges-Louis Leclerc: Naturgeschichte der vierfüssigen Thiere. Erster Band, Troppau, Trassler, 1785. 448 p., $8^{\circ}-\mathrm{Z}$

30.) BufFON, Georges-Louis Leclerc: Naturgeschichte der vierfüssigen Thiere. Zweiter Band, Troppau, Trassler, 1785. 331, [2] p., $8^{\circ}-\mathrm{Z}$

31.) Buffon, Georges-Louis Leclerc: Naturgeschichte der vierfüssigen Thiere. Dritter Band, Troppau, Trassler, 1785. 300, [3] p., $8^{\circ}-\mathrm{Z}$ 
32.) BUfFON, Georges-Louis Leclerc: Naturgeschichte der vierfüssigen Thiere. Vierter Band, Troppau, Trassler, 1785.416 p., $8^{\circ}-\mathrm{Z}$

33.) Buffon, Georges-Louis Leclerc: Naturgeschichte der vierfüssigen Thiere. Fünfter Band, Troppau, Trassler, 1785. 360 p., $8^{\circ}-\mathrm{Z}$

34.) BufFON, Georges-Louis Leclerc: Naturgeschichte der vierfüssigen Thiere. Sechster Band, Troppau, Trassler, 1786. 521 p., $8^{\circ}-\mathrm{Z}$

35.) BufFOn, Georges-Louis Leclerc: Naturgeschichte der vierfüssigen Thiere. Siebenter Band, Brünn, Trassler, 1786. 429, [3] p., $8^{\circ}-\mathrm{Z}$

36.) BufFON, Georges-Louis Leclerc: Naturgeschichte der vierfüssigen Thiere. Achter Band, Brünn, Trassler, 1786. 351, [1] p., $8^{\circ}-\mathrm{Z}$

37.) BuffON, Georges-Louis Leclerc: Naturgeschichte der vierfüssigen Thiere. Neunter Band, Brünn, Trassler, $1786-472$ p., $8^{\circ}-\mathrm{Z}$

38.) BuFFON, Georges-Louis Leclerc: Naturgeschichte der vierfüssigen Thiere. Zehnter Band, Brünn, Trassler, $1786-553$ p., $8^{\circ}-\mathrm{Z}$

39.) BUFFON, Georges-Louis Leclerc: címlap nélkül 56 színes rézkarc emlősállatokról, s.l., s.n., 1786 -56 p., $8^{\circ}-\mathrm{Z}$

40.) BufFON, Georges-Louis Leclerc: Naturgeschichte der vierfüssiger Thiere. Zwölfter Band, Brünn, Trassler, $1789-397$ p., $8^{\circ}-\mathrm{Z}$

41.) Buffon, Georges-Louis Leclerc: Naturgeschichte der vierfüssiger Thiere. Dreizehnter Band, Brünn, Trassler, $1789-410$ p., $8^{\circ}-\mathrm{Z}$

42.) BufFON, Georges-Louis Leclerc: címlap nélkül 55 színes rézkarc emlősállatokról, s.l., s.n., évszám nélkül, -55 p., $8^{\circ}-\mathrm{Z}$

43.) BuFFON, Georges-Louis Leclerc: címlap nélkül 79 színes rézkarc emlősállatokról, s.l., s.n., évszám nélkül - 79 p., $8^{\circ}-\mathrm{Z}$

44.) BUFFON, Georges-Louis Leclerc: címlap nélkül 65 színes rézkarc emlősállatokról, s.1., s.n., évszám nélkül - 65 p., $8^{\circ}-\mathrm{Z}$

45.) Buffon, Georges-Louis Leclerc: Naturgeschichte der Vögel. Erster Band, Brünn, Trassler, 1786 $-421 \mathrm{p} ., 8^{\circ}-\mathrm{Z}$

46.) Buffon, Georges-Louis Leclerc: Naturgeschichte der Vögel. Zweiter Band, Brünn, Trassler, $1787-324$ p., $8^{\circ}-\mathrm{Z}$

47.) BufFon, Georges-Louis Leclerc: Naturgeschichte der Vögel. Dritter Band, Brünn, Trassler, 1787 -356 p., $8^{\circ}-\mathrm{Z}$

48.) BuFFON, Georges-Louis Leclerc: Naturgeschichte der Vögel. Vierter Band, Brünn, Trassler, 1787 -378 p., $8^{\circ}-\mathrm{Z}$

49.) BufFON, Georges-Louis Leclerc: Naturgeschichte der Vögel. Fünfter Band, Brünn, Trassler, $1787-427$ p., $8^{\circ}-\mathrm{Z}$

50.) Buffon, Georges-Louis Leclerc: Naturgeschichte der Vögel. Sechster Band, Brünn, Trassler, $1788-524$ p., $8^{\circ}-\mathrm{Z}$

51.) Buffon, Georges-Louis Leclerc: Naturgeschichte der Vögel. Siebenter Band, Brünn, Trassler, $1788-482$ p., $8^{\circ}-\mathrm{Z}$

52.) BufFON, Georges-Louis Leclerc: Naturgeschichte der Vögel. Achter Band, Brünn, Trassler, 1789 $-621 \mathrm{p} ., 8^{\circ}-\mathrm{Z}$

53.) BUFFON, Georges-Louis Leclerc: címlap nélkül 235 színes rézkarc madarakról, s.l., s.n., évszám nélkül -235 p., $8^{\circ}-\mathrm{Z}$ 
54.) BÜSCHING, Anton Friedrich: Unterricht in der Naturgeschichte, für dejenigen, welche noch wenig oder gar nichts von derselben wissen. Berlin, Wangen, 1776. [2], 189 p., - N

55.) Comenius, Johann Amos: Orbis sensualium pictus quadrilinguis. Noribergae, Endter, 1777. [48], 604, [298] p., $8^{\circ}-\mathrm{N}$

56.) DÉzAllier D'Argenville, Antoine Joseph: Conchyliologie oder Abhandlung von den Schnecken, Muscheln und andern Schaalthieren welche in der See, in süssen Wassern und auf dem Lande gefunden werden, nebst der Zoomorphose oder Abbildung und Beschreibung der Thiere welche die Gehäuse bewohnen. Wien, s.n., 1772. [2], 392, 82, [16] p.-Z

57.)* Dragancich, Joannis Laurentii: Tractus de animalibus subterraneis et insectis. Graecii, Haeredum Widmanstadii, 1741. [6], 156, [6] p., $12^{\circ}-\mathrm{D}$

58.) EBERT, Johann Jacob: Naturlehre für die Jugend. Zweiter Band, Leipzig, Weidmanns Erben und Reich, 1777. 342 p., $8^{\circ}-\mathrm{N}$

59.)* EICHHORN, Johan Conrad: Beytrage zur Naturgeschichte der kleinen Wassertiere die mit blossem Auge nicht können gesehen werden die sich in den Gewässern in und um Danzig befinden. Berlin und Stettin, Nikolai, 1781.94 p., $8^{\circ}-\mathrm{Z}$

60.) ERXLEBEN, Johann Christian Polycarp: Anfangsgründe der Naturgeschichte. Göttingen, Dieterich, 1782.756 p., $8^{\circ}-\mathrm{Z}$

61.) ERXLEBEN, Johann Christian Polycarp: Anfangsgrunde der Naturgeschichte. Wien, von Trattnern, 1787.756 p., $8^{\circ}-\mathrm{Z}$

62.) ERXLeBen, Johann Christian Polycarp: Anfangsgründe der Naturgeschichte. Wien, s.n., 1797. 670 p., $8^{\circ}-\mathrm{Z}$

63.) FRANZIUS, Wolfgang: Historia animalium sacra, in qua plerorumque animalium. Witebergae, Schürer, 1612. [48], 888, [32] p., $8^{\circ}-\mathrm{Z}$

64.) FRANZIUS, Wolfgang: Historia animalium sacra, in qua plerorumque animalium. Wittenbergae, Schürer, 1616. [48], 888, [32] p., $8^{\circ}-\mathrm{Z}$

65.) FRANZIUS, Wolfgang: Historia animalium In qua plerorumqve Animalium praecipuae proprietates in gratiam Studiosorum Theologiae, \& Minisrorum Verbi ad usum eikonologikon breviter accommodantur. Wittenbergae, Bauer, 1659. [56], 1027, [76] p., $12^{\circ}-\mathrm{Z}$

66.) FrANZIUS, Wolfgang: Historia animalium. Amstelaedami, Ravesteinium, 1665. [44], 779, [52] p., $12^{\circ}-\mathrm{Z}$

67.) GÁTI István: $A^{\prime}$ természet históriája, mellyben az ásványoknak, plántáknak és állatoknak három világát, azoknak meg-esmértetö béllyegeivel, természetekkel, hasznokkal, hazájokkal, rendbeszedve és a' gyenge elmékhez alkalmaztatva; mind egygyütt magyar nyelven leg-elöször bocsátjaki Gáti István. Pozsony, Wéber, 1795. 300, [10] p., $8^{\circ}-\mathrm{T}$

68.) GÁTI István: A' természet históriája, mellyben az ásványoknak, plántáknak és állatoknak három világát, azoknak meg-esmértetö béllyegeivel, természetekkel, hasznokkal, hazájokkal, rendbeszedve és a' gyenge elmékhez alkalmaztatva; mind egygyütt magyar nyelven leg-elöször bocsátjaki Gáti István. Pozsony, Wéber, 1798. 300, [10] p., $8^{\circ}-\mathrm{T}$

69.) GESSNER, Conrad: Historiae Animalium Liber III. qui est de Auium natura. Francofurti, Wechel, 1585. [12], 806, [26] p., $2^{\circ}-\mathrm{Z}$

70.) GESSNER, Conrad: Historiae Animalium Liber II. qui est de Quadrupedibus Oviparis. Francofurti, Wechel, 1586. [8], 119 p., $2^{\circ}-\mathrm{Z}$

71.) GeSSNER, Conrad: Historiae Animalium Liber Primus De Quadrupedibus viulparis. Francofurti, Bibliopolio Cambieriano, 1603. [40], 967 p., $2^{\circ}-\mathrm{Z}$ 
72.) GeSSNER, Conrad; Historiae Animalium Liber IV. Qui est de Piscium et Aquatilium animantium natura. Francofurti, Cambieri, 1604. [40], 1052 p., $2^{\circ}-\mathrm{Z}$

73.)* GLEICHEN, Wilhelm Friedrich von: Versuch einer Geschichte der Blattläuse und Blatläusfresser des Ulmenbaums. Nürnberg, s.n., 1787. [8], 28, [2] p., $4^{\circ}-\mathrm{Z}$

74.)* Grubanovics, Josephus: Dissertationes de variorum animalium Natura, et Proprietatibus. Graecii, Widmanstad, 1740. [8], 186, [6] p., $8^{\circ}-\mathrm{D}$

75.)* HiltenbrandT, Anton: Anleitung zur richtigen Erkenntniss der meissten in der Augen fallenden natürlichen Dinge. Zum Gebrauche der Deutschen Schulen in den kaisserl. königl. Staaten. Wien, s.n., $1780-208$ p., $8^{\circ}-\mathrm{T}$

76.) JONSTON, Jan: Theatrum universale omnium animalium quadrupedum. Heilbrunn, Eckebrecht, 1755. [16], 236, [6] p., $2^{\circ}-\mathrm{Z}$

77.)* Jonston, Jan: Theatrum universale omnium de avibus. Heilbrunn, Eckebrecht, 1756. [8] 238 [10] p., $2^{\circ}-\mathrm{Z}$

78.) Jonston, Jan: Theatrum universale omnium animalium insectorum; Historiae naturalis de serepentibus (libri duo). Heilbrunn, Eckebrecht, 1757. [2], 212, [2], 55 [4] p., $2^{\circ}-\mathrm{Z}$

79.)* Jonston, Jan: Historia naturalis de piscibus et cetis Libri V. Heilbrunn, Eckebrecht, 1767. 228 p., $4^{\circ}-\mathrm{Z}$

80.)* Klobius, Justus Fidus: Ambrae historiam ad omnipotens Dei gloriam, et hominum sanitatem. Wittenbergae, Henckel, 1666. [8], 76, [2] p., $4^{\circ}-\mathrm{Z}$

81.) KrAMER, Guilielmi Henrici: Elenchus vegetabilium et animalium per Austriam Inferiorem observatorum Sistens ea in classes et ordines genera et species redacta. Viennae, Pragae et Tergesti, Trattner, 1756. [10], 400, [22] p., $12^{\circ}-\mathrm{Z}$

82.)* KüHN, August Christian: Kurze Anleitung Insecten zu sammeln. Eisenach, s.n., 1783. [8], 182 p., $8^{\circ}-\mathrm{Z}$

83.) LE GRAND, Antoine: Historia Naturae, variis experimentis et ratiociniis elucidata. Londini, s.n., 1680. [16], 431, [16] p., $4^{\circ}-\mathrm{Z}, \mathrm{T}$

84.) LE GRAND, Antoine: Historia Naturae, variis experimentis et ratiociniis elucidata. Londini, Martyn, 1673. [25], 416, [15] p., $8^{\circ}-\mathrm{Z,T}$

85.) LESKE, Nathanael Gottfried: Anfangsgründe der Naturgeschichte. Leipzig, Crusius, 1784. - 681 p., $8^{\circ}-\mathrm{Z}$

86.)* LinNaEus, Carl: Oratio de necessitate peregrinationum intra patriam, ejusque elenchus Animalium per Sueciam observatorum. (Accedunt J. Browallii Examen epicriseos Siegesbeckiance in Systema Plantarum sexuale: et I. Gesneri Dissertationes de partium vegetationis et fructificationis structura, differentia et usu, In quibus Elementa Botanica dilucide explicantur. Lugundi Batavorum, Haak, 1743. - [2], 94,108 p., $8^{\circ}-\mathrm{Z}$

87.) LinNAEUS, Carl: Selectae ex amaenitatibus academicis Caroli Linnaei, dissertationes ad universam naturalem historiam pertinentes, quas edidit et additamentis auxit L.B. e S.I. Graecii, Typis haeredum Uvidmanstadii, 1764. - [7], 316 p., $8^{\circ}-\mathrm{Z}$

88.)* Linnaeus, Carl: Continuatio selectarum ex Amoenitatibus Academicis Caroli Linnaei dissertationes ad universam naturalem historiam pertinentium, quas edidit, et additamentis auxit L.B. e S.I. Graecii, Typis haeredum Uvidmanstadii, 1766. - [4], 297 p., $8^{\circ}-\mathrm{Z}$

89.) Linnaeus, Carl: Selectae ex amaenitatibus academicis Caroli Linnaei dissertationes ad universam naturalem historiam pertinentes, quas edidit et additamentis auxit L.B. e S.I. Graecii, Typis haeredum Uvidmanstadii, 1766. - [4], 297 p., $8^{\circ}-\mathrm{Z}$ 
90.) LinNAEUS, Carl: Systema Naturae per regna tria naturae, secundum classes, ordines, genera, species cum characteribus et differentiis, synonymis, locis. Vindobonae, Trattnern, 1767. - 1327, [37] p., $8^{\circ}-\mathrm{Z}$

91.)* Linnaeus, Carl: Selectae ex amaenitatibus academicis Caroli Linnaei dissertationes ad universam naturalem historiam pertinentes, quas edidit et additamentis auxit L.B. e S.I. Graecii, Typis haeredum Uvidmanstadii, 1769. - [8], 277 p., $8^{\circ}-\mathrm{Z}$

92.) LinNAEUS, Carl: Des Ritters Carl von Linné vollständiges Natursystem: nach der zwölften lateinischen Ausgabe und nach Anleitung des holländischen Houttuynischen Werks mit einer ausführlichen Erklärung / ausgefertiget von Philipp Ludwig Statius Müller. Erster Theil. Von den säugenden Thieren. Nürnberg, Raspe, 1773. - [24], 508, [16] p.; $8^{\circ}-\mathrm{Z}$

93.) Linnaeus, Carl: Des Ritters Carl von Linné vollständiges Natursystem: nach der zwölften lateinischen Ausgabe und nach Anleitung des holländischen Houttuynischen Werks mit einer ausführlichen Erklärung / ausgefertiget von Philipp Ludwig Statius Müller. Zweyter Theil. Von den Vögeln. Nürnberg, Raspe, 1773. - [16], 638, [34] p., $8^{\circ}-\mathrm{Z}$

94.) Linnaeus, Carl: Des Ritters Carl von Linné vollständiges Natursystem: nach der zwölften lateinischen Ausgabe und nach Anleitung des holländischen Houttuynischen Werks mit einer ausführlichen Erklärung / ausgefertiget von Philipp Ludwig Statius Müller. Vierter Theil. Von den Fischen. Nürnberg, Raspe, 1774. - [16], 400, [16] p., $8^{\circ}-\mathrm{Z}$

95.) Linnaeus, Carl: Des Ritters Carl von Linné vollständiges Natursystem: nach der zwölften lateinischen Ausgabe und nach Anleitung des holländischen Houttuynischen Werks mit einer ausführlichen Erklärung / ausgefertiget von Philipp Ludwig Statius Müller. Dritter Theil. Von den Amphibien. Nürnberg, Raspe, 1774. -350, [18] p., $8^{\circ}-\mathrm{Z}$

96.) LinNAEUS, Carl: Des Ritters Carl von Linné vollständiges Natursystem: nach der zwölften lateinischen Ausgabe und nach Anleitung des holländischen Houttuynischen Werks mit einer ausführlichen Erklärung / ausgefertiget von Philipp Ludwig Statius Müller. Fünfter Theil. Von den Insecten. Erster Band, Nürnberg, Raspe, 1774. - [14], 758, [2] p., $8^{\circ}-\mathrm{Z}$

97.) LinnaEus, Carl: Des Ritters Carl von Linné vollständiges Natursystem: nach der zwölften lateinischen Ausgabe und nach Anleitung des holländischen Houttuynischen Werks mit einer ausführlichen Erklärung / ausgefertiget von Philipp Ludwig Statius Müller. Fünfter Theil. Von den Insecten. Zweiter Band, Nürnberg, Raspe, 1775. - [14], 761-1166, [102] p., 8 , - Z

98.) LinnaEus, Carl: Des Ritters Carl von Linné vollständiges Natursystem: nach der zwölften lateinischen Ausgabe und nach Anleitung des holländischen Houttuynischen Werks mit einer ausführlichen Erklärung / ausgefertiget von Philipp Ludwig Statius Müller. Sechster Theil. Von den Würmer. Nürnberg, Raspe, 1775. - [16], 638 p., $8^{\circ}-\mathrm{Z}$

99.) Linnaeus, Carl: Des Ritters Carl von Linné vollständiges Natursystem: nach der zwölften lateinischen Ausgabe und nach Anleitung des holländischen Houttuynischen Werks mit einer ausführlichen Erklärung / ausgefertiget von Philipp Ludwig Statius Müller. Sechster Theil. Von den Corallen. Nürnberg, Raspe, 1775. - [17], 642-960, [110] p., $8^{\circ}-\mathrm{Z}$

100.) Linnaeus, Carl: Des Ritters Carl von Linné vollständiges Natursystem Supplements: und Register: Band über alle sechs Theile oder Classen der Thierrechs. Mit einer ausführlichen Erklärung ausgefertiget von Philipp Ludwig Statius Müller. Nürnberg, Raspe, 1776. - 536 p., 8, $-\mathrm{Z}$

101.) LinNAEUS, Carl: Systema naturae per regna tria naturae. Lipsiae, Beer, 1788. - [6], 500 p., $8^{\circ}-$ Z

102.) MARTINI, Friedrich Heinrich Wilhelm: Allgemeine Geschichte der Natur, in alphabetischer Ordnung. Erster Theil, Berlin und Stettin, Pauli, 1774. - [4], 764 p., $8^{\circ}-\mathrm{Z}$ 
103.) MaRtini, Friedrich Heinrich Wilhelm: Allgemeine Geschichte der Natur, in alphabetischer Ordnung. Zweiter Theil, Berlin und Stettin, Pauli, 1775. - 690 p., $8^{\circ}-\mathrm{Z}$

104.) MARTINI, Friedrich Heinrich Wilhelm: Allgemeine Geschichte der Natur, in alphabetischer Ordnung. Dritter Theil, Berlin und Stettin, Pauli, 1777. - 706 p., $8^{\circ}-\mathrm{Z}$

105.) MARTINI, Friedrich Heinrich Wilhelm: Allgemeine Geschichte der Natur, in alphabetischer Ordnung. Vierter Theil, Berlin und Stettin, Pauli, 1778. - 702 p., $8^{\circ},-\mathrm{Z}$

106.) Martini, Friedrich Heinrich Wilhelm: Allgemeine Geschichte der Natur, in alphabetischer Ordnung. Fünfter Theil, Berlin, Pauli, 1785. - [2], 710 p., $8^{\circ},-\mathrm{Z}$

107.) MARTINI, Friedrich Heinrich Wilhelm: Allgemeine Geschichte der Natur, in alphabetischer Ordnung. Sechster Theil, Berlin, Pauli, 1786. -662 p., $8^{\circ},-\mathrm{Z}$

108.) MARTINI, Friedrich Heinrich Wilhelm: Allgemeine Geschichte der Natur, in alphabetischer Ordnung. Siebenter Theil, Berlin, Pauli, 1787. - [2], 758, [82] p., $8^{\circ}-\mathrm{Z}$

109.) MARTINI, Friedrich Heinrich Wilhelm: Allgemeine Geschichte der Natur, in alphabetischer Ordnung. Achter Theil, Berlin, Pauli, 1789. [6], 832 p., $8^{\circ}-\mathrm{Z}$

110.) MARTINI, Friedrich Heinrich Wilhelm: Allgemeine Geschichte der Natur, in alphabetischer Ordnung. Neunter Theil, Berlin, Pauli, 1790. - [2], 720 p., $8^{\circ}-\mathrm{Z}$

111.) MARTINI, Friedrich Heinrich Wilhelm: Allgemeine Geschichte der Natur, in alphabetischer Ordnung. Zehnter Theil, Berlin, Pauli, 1791. - [2], 840 p., $8^{\circ},-\mathrm{Z}$

112.) MARTINI, Friedrich Heinrich Wilhelm: Allgemeine Geschichte der Natur, in alphabetischer Ordnung. Elfter Theil, Berlin, Pauli, 1793. - [2], 799 p., $8^{\circ},-\mathrm{Z}$

113.) MitTerpacher, Ludwig: Primae Lineae historiae naturalis. In usum gymnasiorum regni Hungariae, et regnorum eidem adnexorum. Budae, Typis ac sumtibus reegiae universitatis, 1795. [4], 118 p., $8^{\circ},-\mathrm{T}$

114.) MitTERPACHER, Ludwig: Compendium Historiae Naturalis. Budae, Regiae Universitatis Pesthensis, 1799. - [4], 457, [3] p., $8^{\circ},-\mathrm{Z}$

115.) MolnAR, Johann Baptist: Zoologicon complexum historiam naturalem animalium. Budae, Typis regiae universitatis, $1780 .-[2], 88$ p., $8^{\circ},-\mathrm{N}$

116.) Nieremberg, Juan Eusebio: Historia naturae maxime peregrinae, Libris XVI. Distincta. Antverpiae, Moreti, $1635-[8], 502$ p., $2^{\circ},-\mathrm{Z}$

117.) Pluche, Antoine: Le spectacle de la Nature, ou entretiens sur les particularités de l'histoire naturelle. tome second, Utrecht, Neaulme, 1735. - [1], 466 p., $12^{\circ},-\mathrm{Z,N}$

118.) Pluche, Antoine: Le spectacle de la Nature, ou entretiens sur les particularités de l'histoire naturelle. tome troisiéme, Utrecht, Neaulme, 1736. - 574 p., $12^{\circ},-\mathrm{Z}, \mathrm{N}$

119.) Pluche, Antoine: Le spectacle de la Nature, ou entretiens sur les particularités de l'histoire naturelle. tome premier, la Haye (= Den Haag), Neaulme, 1739. - [2], 542 p., 12 ${ }^{\circ},-\mathrm{Z}, \mathrm{N}$

120.) Pluche, Antoine: Le spectacle de la Nature, ou entretiens sur les particularités de l'histoire naturelle. tome quatrieme, Utrecht, Neaulme, 1746. -598 p., $12^{\circ},-\mathrm{Z}, \mathrm{N}$

121.)* Poda Von Neuhaus, Nicolaus: Insecta Musei Graecensis, quae in ordines, genera et species juxta systema naturae Caroli Linnaei. Graecii, s.n., 1761. - [8], 127 p., - Z

122.) QuATREMÈRE-DisJONVAL, Denis-Bernard: Neueste Entdeckungen über die Natur der Spinnen und vorzüglich über deren Verhältniß mit den Veränderungen in der Atmosphäre, in wie fern sie nämlich die Beschaffenheit der Witterung voraus anzeigen. Berlin und Leipzig, 1799. - 144 p.,$\mathrm{Z}$

123.) RAFF, Georg Christian: Természethistória a gyermekeknek. Weszprém, Számmer, 1799. - [14], $669,[12]$ p., $8^{\circ},-\mathrm{T}$ 
124.) ReIMARUS, Hermann Samuel: Allgemeine Betrachtungen über die Triebe der Thiere, hauptsächlich über ihre Kunsttriebe. Theil 2, Hamburg, Bohn, 1773. - [8], 232, [15] p., 8॰ , - Z, N

125.) RICHTER, Johann Gottfried Ohnefalsch: Ichthyotheologie, oder: Vernunft und Schriftmasiger Versuch die Menschen aus Betrachtung der Fische zur Bewunderung, Ehrfurcht und Liebe ihres grossen, liebreichen und allein weisen Schöpfers zu führen. Leipzig, Lanckisch, 1754. - [15], $912,[16]$ p., $8^{\circ},-\mathrm{Z}$

126.)* RichTER, Adam Daniel: Lehrbuch einer Natur-Historie zu einem gemeinnützigen Gebrauch wie auch zu Vorlesungen in Schulen eingerichtet und gesammelt. Frankfurt und Leipzig, s.n., 1786. -404 p., $8^{\circ},-\mathrm{T}$

127.) RotHe, Georg: Kurtzer Begriff der Naturlehre. Braeslau und Leipzig, s.n., 1767. - [16], 175 p., $8^{\circ},-\mathrm{N}$

128.)* RudolPh, Daniel Gottlob: Hand-buch oder kurze Anweisung wie man NaturalienSammlungen mit Russen betrachten soll. Leipzig, Rothe, 1766. - [16], 432 p., $8^{\circ},-\mathrm{Z}$

129.) SANDER, Heinrich: Über das Grosse und Schöne in der Natur. Zweyter Band, Leipzig, s.n., 1784. - [6], 338, [6] p., $8^{\circ},-\mathrm{N}$

130.) Schoenbauer, Joseph Anton: Geschichte der schädligen Kolumbatczer Mücken im Bannat, als ein Beytrag zur Naturgeschichte von Ungarn. Wien, Patzowsky, 1795. - [8], 100, [4] p., $4^{\circ},-\mathrm{Z}$

131.) SchranK, Franz von Paula: Enumeratio Insectorum Austriae Indigenorum. Augustae Vindelicorum, apud vidvam Eberhardi Klett et Franck, 1781. - [20], 548, [4] p., 8 , Z

132.) SCOPOLI, Giovanni Antonio: Introductio ad Historiam naturalem sistens genera Lapidum, Plantarum et Animalium. Pragae, Gerle, 1777. - [3], 506, [17] p., $8^{\circ},-\mathrm{Z}$

133.) SEVERINO, Marco Aurelio: Vipera pythia: id est, de viperae natura, veneno, medicina, demonstrationes et experimenta nova. Frambotti, Nápoly, s.n., 1651. - [16], 522, [22] p., 4 , - Z

134.)* Smeathman, Henry: Some account of the termites, which are found in Africa and other hot climates. London, Nichols, 1781. - 56, [2] p., $4^{\circ},-\mathrm{Z}$

135.) SмIтH, Laurids: Über die Natur und Bestimmung der Thiere. Koppenhagen, Popp, 1790. - 279 p., $8^{\circ},-\mathrm{Z}, \mathrm{T}$

136.) SPERLING, Johann: Zoologia physica posthuma. Lipsiae, Berger, 1661. - [12], 466, [89] p., $8^{\circ},-$ $\mathrm{Z}$

137.)* VoIGT, Johann Carl Wilhelm: Gedanken über die Naturkräfte thierischer Körper in dem Zeugungsgeschäfte, besonders der Bienen. Schwarzach b. Kulmbach, s.n., 1778. - 64 p., $8^{\circ},-\mathrm{N}$

138.) Voltaire (François-Marie AROUET): Denkwürdigkeiten der Natur. Berlin und Leipzig, s.n., 1786. - [7], 180 p., $8^{\circ},-\mathrm{Z}, \mathrm{T}$

139.)* WILDE, Jeremias: De Formica. Ambergae apud Schönfeld, s.n., 1615. - [12], 108 p., 8 , - Z

140.)* WULFF, Johann Christoph: Ichthyologia cum Amphibiis regni Borussici. Regiomonti, Kanter, 1765. - [12], 60 p., $8^{\circ},-\mathrm{Z}$

141.) [PILler Mátyás]: Elementa Historiae Naturalis in usum scholarum grammaticarum et gymnasiorum per regnum Hungariae et provincias eidem adnexas. Pars I. Complectens Regnum Animale. Budae, Typis Regiae Universitatis, 1778. - 60 p., $8^{\circ},-\mathrm{T}$

142.) [PILLER Mátyás]: Elementa historiae naturalis in usum scholarum grammaticum et gymnasiorum per Regnum Hungariae et provincias eidem adnexas. Pars I. Complectens Regnum Animale. Budae, Typis Regiae Universitatis, 1781. - 78 p., $8^{\circ},-\mathrm{T}$

143.) [PILLER Mátyás]: Elementa historiae naturalis in usum scholarum grammaticum et gymnasiorum per Regnum Hungariae et provincias eidem adnexas. Pars I. Complectens Regnum Animale. Budae, Typis Regiae Universitatis, 1791. - 141 p., $8^{\circ},-\mathrm{T}$ 
144.) [PILlER Mátyás]: Elementa historiae naturalis in usum scholarum grammaticarum et gymnasiorum per Regnum Hungariae et provincias eidem adnexas. Pars I. Complectens Regnum Animale. Budae et Tyrnaviae, Typis Regiae Universitatis, 1794. - 88 p., $8^{\circ},-\mathrm{T}$

145.) [ZEPLICHAL, Anton Michael]: Unterricht in der Naturgeschichte. Breslau, s.n., 1776. - [12], 173 p., $8^{\circ},-\mathrm{T}$

146.)* szerző nélkül: Neue Anmerkungen über alle Theile der Naturlehre: aus denen Englischen Transactionen, denen Gedenkschriften der Akademie der Wissenschaften in Paris und andern mehr zusammengezogen und gesamlet, Aus dem Französischen übersetzt. Erster Theil, Kopenhagen und Leipzig, Ackermann, 1753. - [28], 476 p., $8^{\circ},-\mathrm{Z}$

147.)* szerző nélkül: Kenntnisse von natürlichen Dingen zum Gebrauche der studierenden Jugend in dem kaiserl. königl. Staaten. Wien, Trattner, 1781. - 197 p., $8^{\circ},-\mathrm{T}$

148.) szerző nélkül: Kenntnisse von natürlichen Dingen zum Gebrauche der studierenden Jugend im Königreich Hungarn und den damit verbundenen Staaten. Ofen und Tyrnau, gedruckt mit königlichen Universitätschriften, 1787. - [6], 186 p., $8^{\circ},-\mathrm{T}$

149.) szerző nélkül: Kenntnisse von natürlichen Dingen zum Gebrauche der studierenden Jungen im Königreich Hungarn und den damit verbundenen Staaten. Ofen und Tyrnau, gedruckt mit königlichen Universitätschriften, 1789. - [8], 183 p., - T

150.)* szerző nélkül: Unterricht für Liebhaber der Canarienvögel. Grätz, Trötscher, 1798. - 70 p., $8^{\circ}$, $-\mathrm{Z}, \mathrm{N}$ 


\title{
Zoology books from the early modern periode - holdings of the Library of the Archabbey of Pannonhalma
}

\author{
GÁBOR BAKONYI ${ }^{1 *} \&$ ZSUZSANNA BAKONYI $^{2}$ \\ ${ }^{1}$ Szent István University, Department of Zoology and Animal Ecology, H-2100 Gödöllő, Páter K. u. 1. \\ *E-mail: bakonyi.gabor@mkk.szie.hu \\ ${ }^{2}$ Hungarian National Széchényi Library, Rare Books Department, H-1014 Budapest, Szent György tér 4-6. E- \\ mail: bakonyi.zsuzsanna@oszk.hu
}

ÁLLATTANI KÖZLEMÉNYEK (2017) 102(1-2): 3-23.

\begin{abstract}
The Library of the Archabbey of Pannonhalma is the oldest one in Hungary. About 200 works were kept here as early as the 11th century. Its history is rich in turns, but the holdings of the library have been increasing more or less continously, and the current collection contains about 400000 volumes. As the Benedictine monks have been active on the teaching and the scientific field, zoological books, among others, were collected during the centuries. However, these books have never been listed and analysed from the zoological point of view in the modern holdings. As a result of our examination, currently 150 volumes of zoology books are to be found in the library from the 16-18th centuries. Most of them are series of books, reference works, dissertations or school-books, but some high-quality scientific works of the era, as books of CONRAD GESSNER, ULISSE ALDROVANDI or CARL LINNÉ are also located in the collection. About one-quarter of the listed books are present only in this library in Hungary. This is a sign that valuable zoological books can be found in church libraries as well.
\end{abstract}

Keywords: LINNÉ, BORKHAUSEN, animal taxonomy, natural history 